Article

\title{
Three-Stage Anaerobic Sequencing Batch Reactor (ASBR) for Maximum Methane Production: Effects of COD Loading Rate and Reactor Volumetric Ratio
}

\author{
Achiraya Jiraprasertwong ${ }^{1}$, Kornpong Vichaitanapat ${ }^{1}$, Malinee Leethochawalit ${ }^{2}$ \\ and Sumaeth Chavadej $1,3, *$ \\ 1 The Petroleum and Petrochemical College, Chulalongkorn University, Bangkok 10330, Thailand; \\ achiraya.jp@gmail.com (A.J.); mix_vc83@hotmail.com (K.V.) \\ 2 Innovative Learning Center, Srinakharinwirot University, Bangkok 10110, Thailand; malineel@g.swu.ac.th \\ 3 Center of Excellence on Petrochemical and Materials Technology, Chulalongkorn University, \\ Bangkok 10330, Thailand \\ * Correspondence: sumaeth.c@chula.ac.th; Tel.: +66-221-8-4139
}

Received: 15 May 2018; Accepted: 5 June 2018; Published: 13 June 2018

\begin{abstract}
A three-stage anaerobic sequencing batch reactor system was developed as a new anaerobic process with an emphasis on methane production from ethanol wastewater. The three-stage anaerobic sequencing batch reactor system consisted of three bioreactors connected in series. It was operated at $37^{\circ} \mathrm{C}$ with a fixed recycle ratio of 1:1 (final effluent flow rate to feed flow rate) and the washout sludge from the third bioreactor present in the final effluent was allowed to be recycled to the first bioreactor. The $\mathrm{pH}$ of the first bioreactor was controlled at 5.5, while the $\mathrm{pH}$ values of the other two bioreactors were not controlled. Under the optimum chemical oxygen demand loading rate of $18 \mathrm{~kg} / \mathrm{m}^{3} \mathrm{~d}$ (based on the feed chemical oxygen demand load and total volume of the three bioreactors) with a bioreactor volumetric ratio of 5:5:20, the system provided the highest gas production performance in terms of yields of both hydrogen and methane and the highest overall chemical oxygen demand removal. Interestingly, the three-stage anaerobic sequencing batch reactor system gave a much higher energy production rate and a higher optimum chemical oxygen demand loading rate than previously reported anaerobic systems since it was able to maintain very high microbial concentrations in all bioreactors with very high values of both alkalinity and solution $\mathrm{pH}$, especially in the third bioreactor, resulting in sufficient levels of micronutrients for anaerobic digestion.
\end{abstract}

Keywords: three-stage anaerobic sequencing batch reactor (ASBR); hydrogen and methane production; mesophilic temperature; reactor volumetric ratio

\section{Introduction}

The production of biogas via anaerobic digestion processes has gained increasing interest worldwide due to being environmentally friendly and having a high energy yield [1-10]. The use of a two-stage process can improve process efficiency in terms of biogas production compared to single-stage anaerobic systems [11-15]. The anaerobic digestion process consists of four sequential steps: (i) hydrolysis (organic polymers are hydrolysed to water-soluble organic monomers such as sugars, and amino acids); (ii) acidogenesis (water-soluble organic monomers are converted to short chain fatty acids, carbon dioxide $\left(\mathrm{CO}_{2}\right)$, hydrogen $\left(\mathrm{H}_{2}\right)$, and alcohols by acidogens); (iii) acetogenesis (large molecular weight organic acids are further consumed by acetogens to produce acetic acid (HAc), $\mathrm{CO}_{2}$ and $\mathrm{H}_{2}$ ) and (iv) methanogenesis (acetic acid is finally converted to methane $\left(\mathrm{CH}_{4}\right)$ and $\mathrm{CO}_{2}$, and $\mathrm{H}_{2}$ is also consumed with $\mathrm{CO}_{2}$ to produce $\left.\mathrm{CH}_{4}\right)[2,16,17]$. The groups of bacteria involved in each step have different growth rates and require different environmental conditions [14]. Accordingly, 
a three-stage anaerobic process was hypothesized to give a higher process performance than singleand two-stage anaerobic processes, since it could provide suitable conditions in each bioreactor to meet the environmental requirements for each step of anaerobic decomposition. Indeed, previous work has stated that a three-stage upflow anaerobic sludge blanket (UASB) system could provide high values for both the overall chemical oxygen demand (COD) removal and the total energy yield [18].

In this study, a three-stage anaerobic sequencing batch reactor (ASBR) system treating ethanol wastewater under a mesophilic temperature was operated at different COD loading rates to produce both $\mathrm{H}_{2}$ and $\mathrm{CH}_{4}$ with an emphasis on maximum $\mathrm{CH}_{4}$ production. The $\mathrm{pH}$ of the first bioreactor was controlled at 5.5, whereas the $\mathrm{pH}$ values of the other two bioreactors were not controlled. In order to minimize the quantity of the $\mathrm{NaOH}$ solution used for $\mathrm{pH}$ adjustment, the final effluent from the third bioreactor was recycled to the first bioreactor with a fixed recycle ratio of 1:1 (final effluent flow rate to feed flow rate). To maximize the $\mathrm{CH}_{4}$ production efficiency, the washout sludge present in the final effluent was recycled to the first bioreactor. Based on the different growth rates of the three groups of bacteria, the volumetric ratio of the three bioreactors was varied in order to maximize the production rate of $\mathrm{CH}_{4}$.

\section{Materials and Methods}

\subsection{Seed Sludge Preparation}

The seed sludge, which had been collected from the bottom of the UASB treating ethanol wastewater at Sapthip Co., Ltd., Lopburi, Thailand, was filtered through a $1 \mathrm{~mm}$ sieve in order to remove all large solid particles. For the first bioreactor, the seed sludge was heat-treated by boiling at $95{ }^{\circ} \mathrm{C}$ for 15 min to eliminate any $\mathrm{H}_{2}$-consuming bacteria and to enrich principally $\mathrm{H}_{2}$-producing bacteria [19-22], while the sieved seed sludge without heat-treatment was directly added to the second and third bioreactors. After adding the seed sludge, tap water was used to fill up all three bioreactors. The microbial concentration, in terms of mixed liquid volatile suspended solids (MLVSS), for the start-up in this study was about $5700 \mathrm{mg} / \mathrm{L}$ for each bioreactor.

\subsection{Substrate Preparation}

The ethanol wastewater was kindly supplied by the same factory, which uses cassava roots as the raw material for ethanol production. The ethanol wastewater mainly came from the bottom of the distillation columns, and it also contained a large quantity of unfermented cassava roots. Hence, it was sieved to remove these large solid particles and kept at $4{ }^{\circ} \mathrm{C}$ until use. The ethanol wastewater was used in this study without nutrient addition because it had a COD:nitrogen:phosphorous (COD:N:P) ratio of 100:2.3:0.7 (by weight) (Table 1), indicating that sufficient amounts of nitrogen and phosphorus were available for anaerobic decomposition according to the theoretical threshold ratio of COD:N:P of 100:1:0.4 [19,23,24].

Table 1. Characteristics of the ethanol wastewater used in this study.

\begin{tabular}{ccc}
\hline Parameter & Units & Value \\
\hline $\mathrm{pH}$ & - & 3.72 \\
Total chemical oxygen demand (COD) & $\mathrm{mg} / \mathrm{L}$ & 80,000 \\
Total volatile fatty acids (VFA) & $\mathrm{mg} / \mathrm{L}$ as HAc & 12,600 \\
Ethanol concentration & $\mathrm{mg} / \mathrm{L}$ & 530 \\
Total suspended solids (TSS) & $\mathrm{mg} / \mathrm{L}$ & 31,700 \\
Total phosphorous (P) & $\mathrm{mg} / \mathrm{L}$ & 1070 \\
Total nitrogen (N) & $\mathrm{mg} / \mathrm{L}$ & 825 \\
COD:N:P & by weight & $100: 1.4: 1.8$ \\
\hline
\end{tabular}




\subsection{ASBR Setup and Operation}

Figure 1 schematically illustrates the experimental set up of the three-stage ASBR system, which consisted of three bioreactors connected in series. All bioreactors were made from polyvinyl chloride pipes in order to inhibit the photosynthetic activities of bacteria and algae. The temperature of each bioreactor was controlled at $37^{\circ} \mathrm{C}$ using a temperature controller connected to a heater [5]. The three-stage ASBR system was operated at either 6 or 8 cycles per day. At 6 cycles/d, each cycle of operation consisted of feeding (15 min), reacting (120 min), settling (90 min) and decanting (15 min). The time for all steps of each cycle was set by a programmable logic controller (PLC). The $\mathrm{pH}$ in the first bioreactor was controlled at 5.5 using a pH controller (Extech, 48PH2, Waltham, MA, USA) [5] with a dosing pump for feeding a $4 \%(w / v) \mathrm{NaOH}$ solution, while the $\mathrm{pH}$ value in the other two bioreactors was not controlled. In order to minimize the consumption of $\mathrm{NaOH}$ for $\mathrm{pH}$ adjustment in the first bioreactor, the effluent of the third bioreactor was fed to the first bioreactor at a constant recycle ratio of 1:1 (final effluent flow rate to feed flow rate).

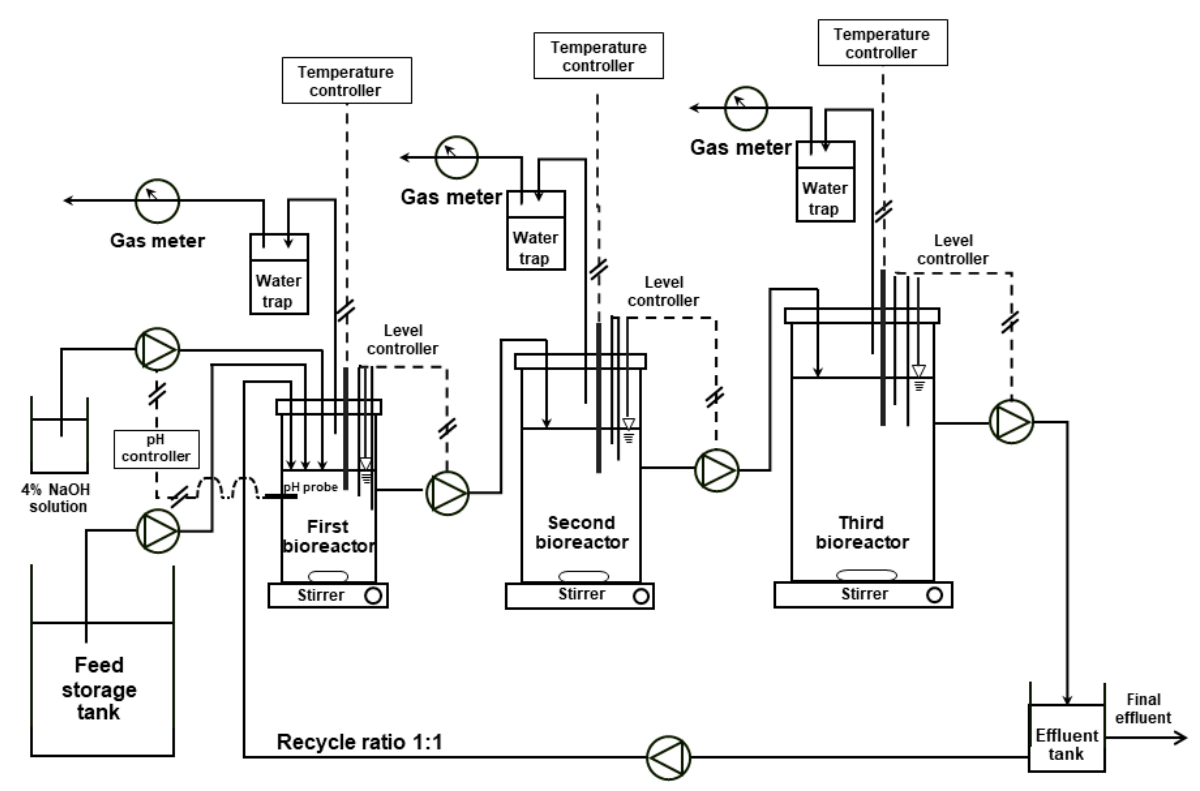

Figure 1. Schematic representation of the three-stage anaerobic sequencing batch reactor (ASBR) system.

For the feeding step, both the ethanol wastewater and the final effluent (without sedimentation) were introduced to the first bioreactor using two separate peristaltic pumps. For the reacting step, a magnetic stirrer ( $400 \mathrm{rpm}$ ) was used to obtain homogeneous mixing in each bioreactor. For the settling step, the microbial cells in all three bioreactors were allowed to settle by turning off the magnetic stirrers. For the final decanting step, the clarified liquid in each bioreactor was drained out by a peristaltic pump connected with a level probe. For any desired COD loading rate, the studied system was operated to reach a steady state condition before taking effluent and produced gas samples for analyses and measurements. The steady state was justified when the COD values and gas production rates of each bioreactor were invariant over time ( $<5 \%$ standard derivation).

For the first part, the three-stage ASBR system was operated at a COD loading rate range of $15-21 \mathrm{~kg} / \mathrm{m}^{3} \mathrm{~d}$ at 6 cycles/d because it was a continuation from previous work, where the optimum COD loading rate was $15 \mathrm{~kg} / \mathrm{m}^{3} \mathrm{~d}$ [25]. The liquid working volumes were fixed at 4,6 and $20 \mathrm{~L}$ for the first, second and third bioreactors, respectively. In this set up, the system was found to provide the highest $\mathrm{CH}_{4}$ production efficiency at a COD loading rate of $18 \mathrm{~kg} / \mathrm{m}^{3} \mathrm{~d}$. The higher optimum COD loading rate in the present study than that obtained from the previous investigation [25], resulted from the higher microbial concentrations in all bioreactors and the recycled methanogens present in the final effluent to the first bioreactor in the present work. 
For the second part, the three-stage ASBR system was operated at a fixed COD loading rate of $18 \mathrm{~kg} / \mathrm{m}^{3} \mathrm{~d}$, a fixed total volume of all three bioreactors of $30 \mathrm{~L}$ and 8 cycles/d with different volumetric ratios of the three bioreactors of 4:6:20, 5:5:20, 4:8:18 and 6:6:18 (L:L:L). For the operation of 8 cycles/d, the total time for each 3 -h cycle consisted of $10 \mathrm{~min}$ of feeding, $70 \mathrm{~min}$ of reacting, $90 \mathrm{~min}$ of settling and $10 \mathrm{~min}$ of decanting.

\subsection{Measurements and Analytical Methods}

The gas production rate of each bioreactor was measured by a gas meter (TGO5/5, Ritter, Germany). The produced gas composition was determined by gas chromatography using a Perkin-Elmer AutoSystem instrument (Waltham, MA, USA) equipped with a thermal conductivity detector (TCD) and two packed columns in series (HayeSep D 100/120 mesh and Altech, Molecular sieve (Flemington, NJ, USA)). The injector, column and detector temperatures were kept constant at 150, 60 and $200^{\circ} \mathrm{C}$, respectively. Argon was used as a carrier gas. The feed and effluent (taken from the decanting step) samples were analysed for COD, total volatile fatty acids (VFA) concentration, VFA composition, volatile suspended solids (VSS), nitrogen and phosphorus. The COD values were determined by the dichromate oxidation method using a controllable heating block (DRB200, $\mathrm{HACH}$, Loveland, CO, USA), and the absorbance was measured by a spectrophotometer (DR3800, $\mathrm{HACH}$, Loveland, CO, USA) according to Standard Methods [26]. The VFA composition and total VFA concentration were determined by a high-performance liquid chromatograph (HPLC; LC-20A, Shimadzu, Kyoto, Japan), with a refractive index detector (RID; RID-20A, Shimadzu, Japan) and an Aminex HPX-87H column, (Bio-Rad Lab, Hercules, CA, USA). A $5 \mathrm{mM} \mathrm{H}_{2} \mathrm{SO}_{4}$ solution was used as the mobile phase at a flow rate of $0.6 \mathrm{~mL} / \mathrm{min}$ at $60{ }^{\circ} \mathrm{C}$. All trace elements, including $\mathrm{Fe}, \mathrm{Cu}, \mathrm{Ni}, \mathrm{Co}, \mathrm{Mn}, \mathrm{Zn}$, and $\mathrm{Mo}$ and $\mathrm{Na}$ present in feed and effluent samples were analysed by atomic absorption spectrophotometry (AAS; SpectrAA 300, Varian Inc., Palo Alto, CA, USA). The VSS of the effluent samples taken from the decanting step and the MLVSS taken during the reacting step were used to represent the microbial washout from each bioreactor and the microbial concentration in each bioreactor, respectively. Both VSS and MLVSS were analysed according to Standard Methods [26]. Organic nitrogen was analysed by the diazotization and cadmium reduction method while inorganic nitrogen components were analysed by the salicylate method with TNT persulfate digestion ( $\mathrm{HACH}$, Loveland, $\mathrm{CO}, \mathrm{USA})$. The total phosphorous contents in the feed and effluent samples were determined by the molybdovanadate method with the acid persulfate digestion method (HACH, Loveland, CO, USA).

\subsection{Calculation}

For any studied COD loading rate, all experimental data were averaged with error bars from at least 5 data points obtained under the steady state condition. The process performance of the three-stage ASBR system was determined in terms of the gas production rates, yields and specific gas production rates (SHPR for $\mathrm{H}_{2}$ and SMPR for $\mathrm{CH}_{4}$ ) of $\mathrm{H}_{2}$ and $\mathrm{CH}_{4}$, as described in our previous studies $[20,23,24,27]$. This following section is divided by subheadings. It should provide a concise and precise description of the experimental results, their interpretation as well as the experimental conclusions that are drawn.

\section{Results and Discussion}

\subsection{Part I: Effect of COD Loading Rate}

\subsubsection{Process Performance of the First Bioreactor}

Figure 2a shows the effect of the COD loading rate on the COD removal level and gas production rate in the first bioreactor. Both the COD removal and gas production rate increased when the COD loading rate was increased from 15 to $18 \mathrm{~kg} / \mathrm{m}^{3} \mathrm{~d}$ to maximum values of $49.6 \%$ for COD removal 
and $11.8 \mathrm{~L} / \mathrm{d}$ for gas production. This can be explained by the fact that higher COD loading rates gave higher levels of available substrates for the microbes to produce gaseous products. However, further increasing the COD loading rate from 18 to $21 \mathrm{~kg} / \mathrm{m}^{3} \mathrm{~d}$ drastically decreased both the COD removal level and gas production rate. This was likely to be due to the toxicity resulting from VFA accumulation, as experimentally confirmed by the results of VFA (Figure 2c) and discussed below.

As shown in Figure $2 b$, the composition of gas produced by the first bioreactor consisted mainly of $\mathrm{CO}_{2}$ and $\mathrm{CH}_{4}$ with a small amount of $\mathrm{H}_{2}$. The $\mathrm{CH}_{4}$ concentration slightly decreased with an increasing COD loading rate, while the $\mathrm{CO}_{2}$ concentration showed the opposite trend. The $\mathrm{H}_{2}$ content in the produced gas was very low (less than $3 \%$ ) and only slightly varied with the COD loading rate. The very low $\mathrm{H}_{2}$ concentration in the first bioreactor resulted from the accumulation of the methanogens, which was caused by the sludge presented in the final effluent from the third bioreactor being recycled to the first bioreactor. Hence, most of the produced $\mathrm{H}_{2}$ was consumed in the first bioreactor.
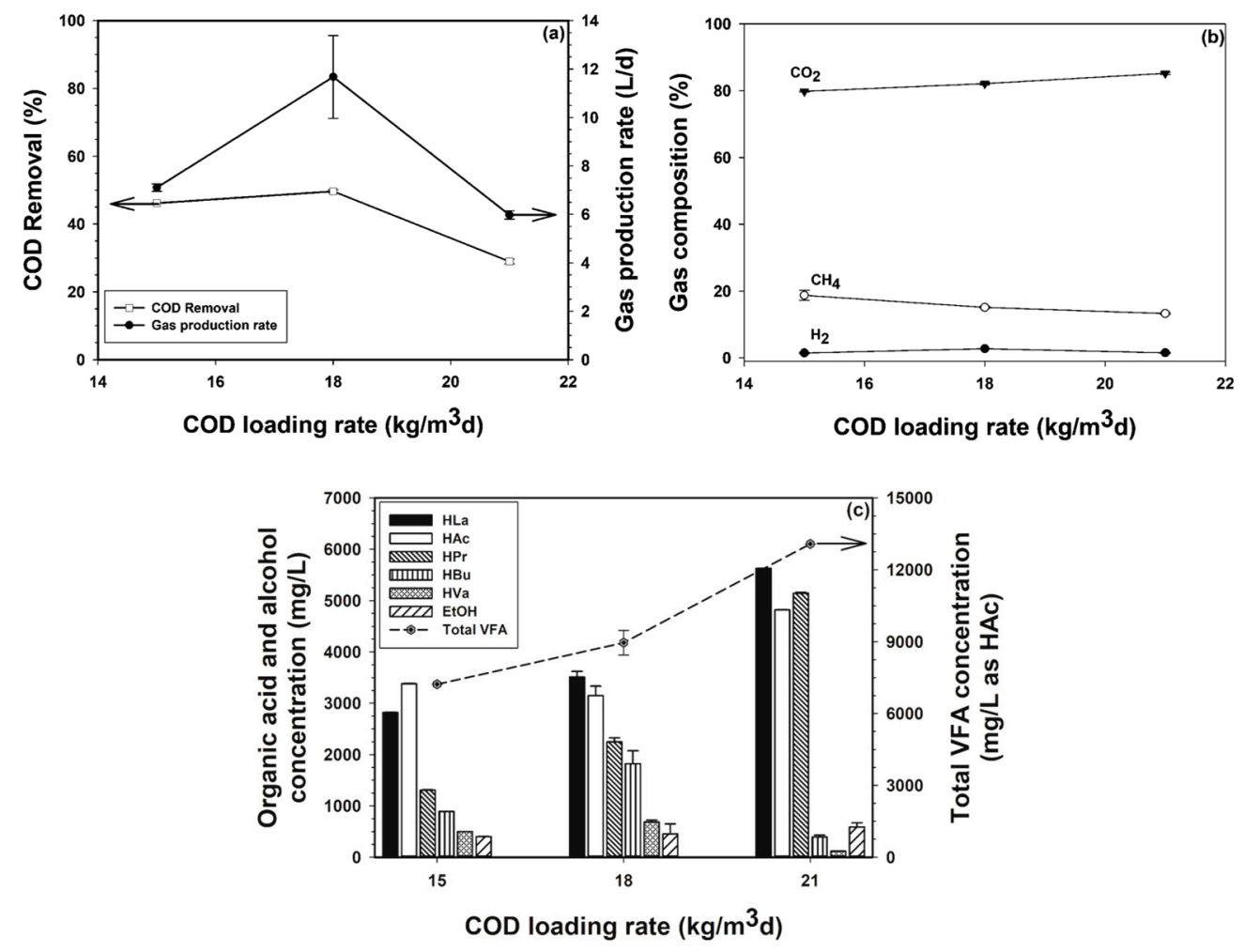

Figure 2. Effect of the COD loading rate on the (a) COD removal and gas production rate, (b) gas composition and (c) total VFA concentration and VFA composition of the first bioreactor operated at $37^{\circ} \mathrm{C}$ and 6 cycles $/ \mathrm{d}$.

Figure 2c shows the total VFA concentration and VFA composition as a function of the COD loading rate. The total VFA concentration progressively increased with an increasing COD loading rate. The composition of the produced gas varied, depending on the COD loading rate. For any given COD loading rate, the produced VFA contained large amounts of lactic acid (HLa), acetic acid (HAc), and propionic acid (HPr) with small quantities of butyric acid $(\mathrm{HBu})$ and valeric acid (HVa). Note that HLa was the most prevalent organic acid, in terms of concentration, in the studied range of the COD loading rate. The very high HLa concentrations in the first bioreactor of the studied three-stage ASBR were very different from those previously reported in single- and two-stage anaerobic systems, which, in contrast, showed very low concentrations of HLa $[20,28,29]$. The very high concentration range of HLa in the first bioreactor of the studied three-stage ASBR system resulted from the high COD loading rates, which were about three- and two-fold higher than those used in single- and two-stage high rate 
anaerobic systems, respectively. The high COD loading rate range with the acidic condition of $\mathrm{pH} 5.5$ observed in this study suggests that the acidogenic step was dominant in the first bioreactor and so the main products were various organic acids with a small amount of ethanol $(\mathrm{EtOH})$, as shown in the following biochemical reactions summarized in Equations (1)-(9) [20,28,29].

$$
\begin{gathered}
\mathrm{C}_{6} \mathrm{H}_{12} \mathrm{O}_{6}+2 \mathrm{H}_{2} \mathrm{O} \rightarrow 2 \mathrm{CH}_{3} \mathrm{COOH}(\mathrm{HAc})+2 \mathrm{CO}_{2}+4 \mathrm{H}_{2} \\
\mathrm{C}_{6} \mathrm{H}_{12} \mathrm{O}_{6} \rightarrow \mathrm{CH}_{3}\left(\mathrm{CH}_{2}\right)_{2} \mathrm{COOH}(\mathrm{HBu})+2 \mathrm{CO}_{2}+2 \mathrm{H}_{2} \\
\mathrm{C}_{6} \mathrm{H}_{12} \mathrm{O}_{6}+2 \mathrm{H}_{2} \rightarrow 2 \mathrm{CH}_{3} \mathrm{CH}_{2} \mathrm{COOH}(\mathrm{HPr})+2 \mathrm{H}_{2} \mathrm{O} \\
\mathrm{CH}_{3} \mathrm{CH}_{2} \mathrm{COOH}(\mathrm{HPr})+\mathrm{CH}_{3}\left(\mathrm{CH}_{2}\right)_{2} \mathrm{COOH}(\mathrm{HBu}) \rightarrow \mathrm{CH}_{3}\left(\mathrm{CH}_{2}\right)_{3} \mathrm{COOH}(\mathrm{HVa})+\mathrm{CH}_{3} \mathrm{COOH}(\mathrm{HAc}) \\
\mathrm{CH}_{3} \mathrm{CH}_{2} \mathrm{COOH}(\mathrm{HPr})+\mathrm{CH}_{3} \mathrm{COOH}(\mathrm{HAc})+\mathrm{H}_{2} \rightarrow \mathrm{CH}_{3}\left(\mathrm{CH}_{2}\right)_{3} \mathrm{COOH}(\mathrm{HVa})+2 \mathrm{H}_{2} \mathrm{O} \\
\mathrm{CH}_{3} \mathrm{CH}_{2} \mathrm{COOH}(\mathrm{HPr})+2 \mathrm{CO}_{2}+6 \mathrm{H}_{2} \rightarrow \mathrm{CH}_{3}\left(\mathrm{CH}_{2}\right)_{3} \mathrm{COOH}(\mathrm{HVa})+4 \mathrm{H}_{2} \mathrm{O} \\
\mathrm{C}_{6} \mathrm{H}_{12} \mathrm{O}_{6} \rightarrow 2 \mathrm{CH}_{3} \mathrm{CHOHCOOH}(\mathrm{HLa}) \\
\mathrm{C}_{6} \mathrm{H}_{12} \mathrm{O}_{6} \rightarrow 2 \mathrm{CH}_{3} \mathrm{CH}_{2} \mathrm{OH}(\mathrm{EtOH})+2 \mathrm{CO}_{2}
\end{gathered}
$$

In addition, $\mathrm{EtOH}$ can be also produced from the reaction between $\mathrm{HAc}$ and $\mathrm{H}_{2}$, as shown in Equation (9) [24].

$$
\mathrm{CH}_{3} \mathrm{COOH}(\mathrm{HAc})+2 \mathrm{H}_{2} \rightarrow \mathrm{CH}_{3} \mathrm{CH}_{2} \mathrm{OH}(\mathrm{EtOH})+\mathrm{H}_{2} \mathrm{O}
$$

As shown in Figure 2c, the total VFA concentration steadily increased with an increasing COD loading rate. In other words, VFA gradually accumulated in the system when the COD loading rate increased [30]. The results show that the toxic level of total VFA to the acidogens was around $10,000 \mathrm{mg} / \mathrm{L}$ as HAc, which is consistent with previous reports [20,23]. Interestingly, among all of the produced VFAs, the highest increase was HPr and followed by HLa and HAc while HBu and HVa varied insignificantly when the COD loading rate increased. Again, the results suggest that the acidogenic step was dominant in the first bioreactor. The unusually high concentration of HLa resulted from the very high COD loading rate conditions.

\subsubsection{Process Performance of the Second Bioreactor}

The effects of the COD loading rate on the COD removal and gas production rate of the second bioreactor are presented in Figure 3a. The COD removal profile showed the same trend as that in the first bioreactor. The highest COD removal of $55.5 \%$ was obtained at the optimum COD loading rate of $18 \mathrm{~kg} / \mathrm{m}^{3} \mathrm{~d}$, while the lowest COD removal of $22.2 \%$ was found at the highest COD loading rate of $21 \mathrm{~kg} / \mathrm{m}^{3} \mathrm{~d}$. The gas production rate steadily declined as the COD loading rate increased.

The biogas produced in the second bioreactor contained mainly $\mathrm{CH}_{4}$ and $\mathrm{CO}_{2}$ with a small content of $\mathrm{H}_{2}$ (lower than $1 \%$ ). The $\mathrm{CH}_{4}$ concentration slightly increased with an increasing COD loading rate and reached a maximum value at a COD loading rate of $18 \mathrm{~kg} / \mathrm{m}^{3} \mathrm{~d}$ and then declined significantly at the higher COD loading rate of $21 \mathrm{~kg} / \mathrm{m}^{3} \mathrm{~d}$. The profile of $\mathrm{CO}_{2}$ content in the produced biogas exhibited the opposite trend to that of $\mathrm{CH}_{4}$. The same explanation for the effect of the COD loading rate on the process performance of the first bioreactor can be used for that of the second bioreactor.

Figure $3 \mathrm{c}$ shows the total VFA concentration and VFA composition as a function of the COD loading rate. The total VFA concentration linearly increased with an increasing COD loading rate. At a COD loading rate lower than the optimum value, the produced VFAs contained mainly HPr and HAc with small amounts of $\mathrm{HBu}$ and HVa. When the COD loading rate increased from 15 to $18 \mathrm{~kg} / \mathrm{m}^{3} \mathrm{~d}$, all organic acids increased significantly except for a small increase in HPr. At the highest COD loading rate, representing the overload condition, the formation of HLa appeared with increased levels of all of the organic acids. The decreased COD removal, gas production rate and $\% \mathrm{CH}_{4}$ beyond the optimum COD loading rate $\left(18 \mathrm{~kg} / \mathrm{m}^{3} \mathrm{~d}\right)$ resulted from the toxicity of the VFA accumulation. The VFA 
compositions and the produced gas in the first and second bioreactors suggest that the acetogenic step was dominant with significant methanogenic activity in the second bioreactor under these high COD loading rates. The profile of total VFA concentration in the second bioreactor indicated that the toxicity level of VFA to the acetogens was around $6000 \mathrm{mg} / \mathrm{L}$ as HAc.
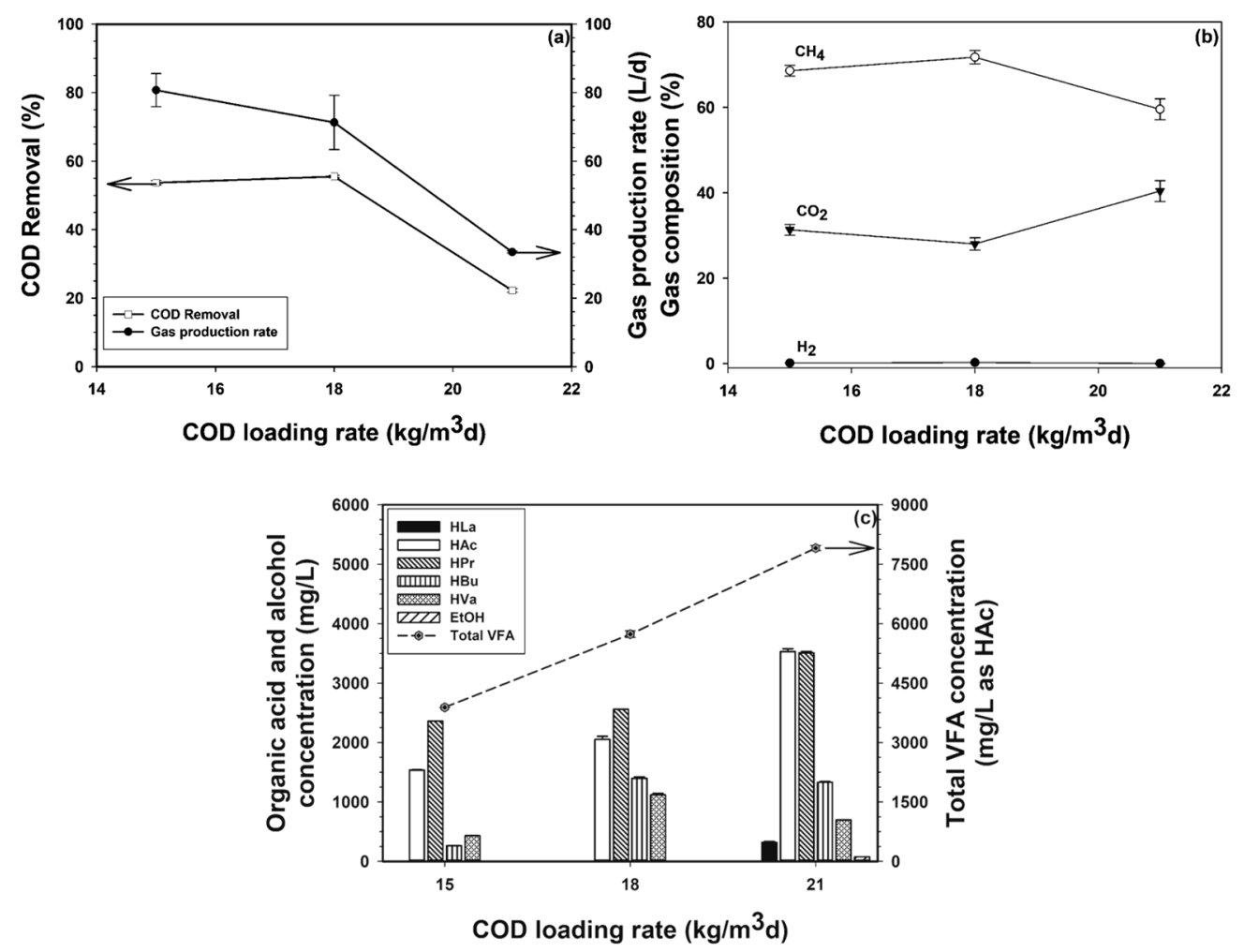

Figure 3. Effect of the COD loading rate on the (a) COD removal and gas production rate, (b) gas composition and (c) total VFA concentration and VFA composition of the second bioreactor operated at $37^{\circ} \mathrm{C}$ and 6 cycles/d.

\subsubsection{Process Performance of the Third Bioreactor}

The COD removal and gas production rate in the third bioreactor steadily increased with an increasing COD loading rate (Figure $4 a$ ). As shown in Figure $4 b$, the produced gas contained only $\mathrm{CH}_{4}$ and $\mathrm{CO}_{2}$ without $\mathrm{H}_{2}$. The concentrations of both $\mathrm{CH}_{4}$ and $\mathrm{CO}_{2}$ remained almost unchanged under the studied COD loading rates. A comparison of the $\mathrm{CH}_{4}$ contents in the produced gas in all three bioreactors revealed a very high $\mathrm{CH}_{4}$ concentration (about $80 \%$ ) in the produced gas of the third bioreactor, suggesting that methanogenesis with a high hydrogenotrophic pathway activity was dominant in the system.

As shown in Figure 4c, the total VFA concentration increased with an increasing COD loading rate. The produced VFAs contained mainly HAc and HPr with small amounts of HBu and HVa. All VFAs increased with increasing COD loading rates, with the highest increase being observed for HAc. The results suggest that the rate of the acetogenic step increased with an increasing COD loading rate in the third bioreactor.

The increased gas production rate and COD removal with increasing COD loading levels suggest that the process was not markedly affected by the inhibition of methanogens by the accumulation of VFA under these high COD loading rates. Previous studies at lower COD loading rates found the toxic level of VFA to methanogens to be in the range of $400-800 \mathrm{mg} / \mathrm{L}$ as HAc [24,25]. The very high tolerance ability of the methanogens in the third bioreactor to withstand the very high VFA concentration (up to $2100 \mathrm{mg} / \mathrm{L}$ as HAc) resulted from the high total alkalinity (about $6500 \mathrm{mg} / \mathrm{L}$ as 
$\mathrm{CaCO}_{3}$ ) and high solution $\mathrm{pH}(7.5)$ in the third bioreactor. The higher the alkalinity and $\mathrm{pH}$, the higher the fraction of produced VFA in dissociated (ionized) forms which are less toxic than the free acid forms. This is one reason why the developed three-stage ASBR system could provide an optimum COD loading rate that was much higher than those of both single- and two-stage anaerobic processes.
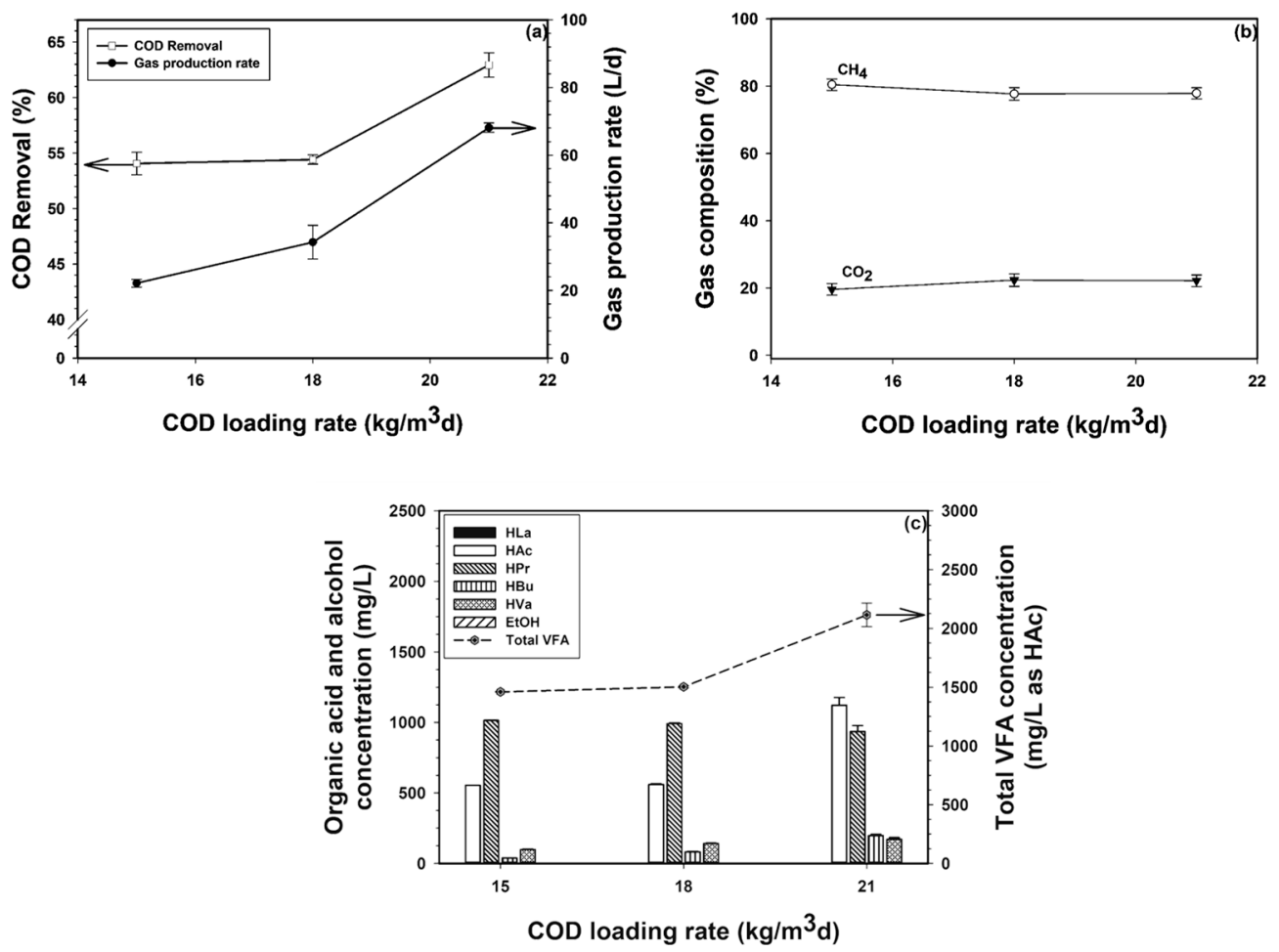

Figure 4. Effect of the COD loading rate on the (a) COD removal and gas production rate, (b) gas composition and (c) total VFA concentration and VFA composition of the third bioreactor operated at $37^{\circ} \mathrm{C}$ and 6 cycles $/ \mathrm{d}$.

\subsubsection{Microbial Concentrations and Microbial Washout Levels}

The effects of the COD loading rate on the MLVSS (representing the microbial concentration) and the effluent VSS (representing the microbial washout) of each bioreactor are shown in Figure 5. For the first bioreactor, as the COD loading rate increased, the MLVSS gradually decreased, while the second and third bioreactors both showed the opposite trend. The microbial washout profile of each bioreactor increased and reached a maximum level at the optimum COD loading rate. Beyond the optimum COD loading rate, the microbial washout slightly decreased when the COD loading rate increased from 18 to $21 \mathrm{~kg} / \mathrm{m}^{3} \mathrm{~d}$. The very high concentrations of microbial cells in all bioreactors resulted from both the recycling of the microbial sludge from the third bioreactor to the first bioreactor and the long operation time (12-24 months) without the withdrawal of excess sludge from the system under the high COD loading rate conditions. The very high microbial concentration in all bioreactors was the main reason why the three-stage ASBR system exhibited a high process performance, compared to single- and two-stage anaerobic processes. 


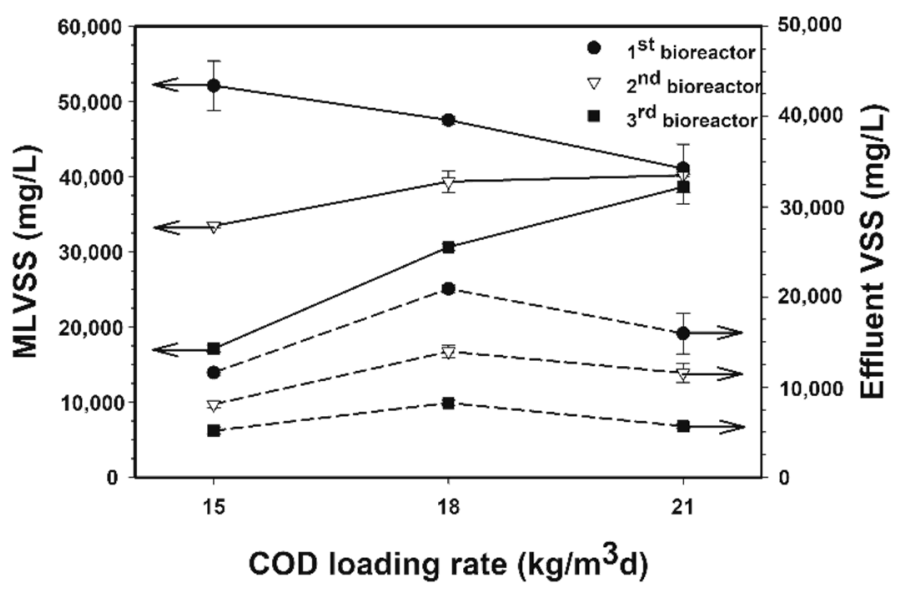

Figure 5. Mixed liquid volatile suspended solids (MLVSS) and effluent VSS of the three-stage ASBR system.

\subsubsection{Micronutrients}

Sufficient quantities of nutrients are needed for both high bacterial activity and growth in anaerobic digestion [31]. Apart from the macronutrients $\mathrm{N}$ and $\mathrm{P}$, trace elements (micronutrients), such as $\mathrm{Co}, \mathrm{Cu}, \mathrm{Fe}, \mathrm{Mo}, \mathrm{Mn}, \mathrm{Ni}$ and $\mathrm{Zn}$, are also essential for the metabolic activity of anaerobes [32-34]. Fundamentally, various divalent cations $\left(\mathrm{M}^{2+}\right)$ can chemically combine with dissolved sulfide ion $\left(\mathrm{S}^{2-}\right)$ dissociated from the produced hydrogen sulfide, as shown in Equations (10)-(13) to form insoluble metal sulfides [35], resulting in the shortage of some micronutrients in anaerobic bioreactors.

$$
\begin{gathered}
\mathrm{H}_{2} \mathrm{~S}_{(\mathrm{g})} \leftrightarrow \mathrm{H}_{2} \mathrm{~S}_{(\mathrm{l})} \\
\mathrm{H}_{2} \mathrm{~S}_{(\mathrm{l})} \leftrightarrow \mathrm{H}^{+}+\mathrm{HS}^{-} \\
\mathrm{HS}-\leftrightarrow \mathrm{H}^{+}+\mathrm{S}^{2-} \\
\mathrm{M}^{2+}+\mathrm{S}^{2-} \leftrightarrow \mathrm{MS}(\mathrm{s})
\end{gathered}
$$

The concentrations of some micronutrients in the feed and the effluents of all ASBR bioreactors at different COD loading rates compared to the theoretical values for anaerobic digestion are presented in Table 2. The ethanol wastewater contained sufficient amounts of all micronutrients. For any COD loading rate, the profiles of all micronutrient concentrations declined markedly after passing through each bioreactor, presumably due to the precipitation of metal sulfides from the reaction of the produced sulfide ions with all micronutrients in the form of divalent cations [34]. Surprisingly, all micronutrients were still present in sufficient amounts for anaerobic digestion in the studied three-stage ASBR system, in contrast to most single- and two-stage anaerobic systems that have a shortage of some micronutrients [34,36-38]. The results can be explained by the fact that the three-stage ASBR system of this study had a very high VFA concentration with an extremely high alkalinity and solution $\mathrm{pH}\left(5000-5400 \mathrm{mg} / \mathrm{L}\right.$ as $\mathrm{CaCO}_{3}$ and $\mathrm{pH}$ 6-7 for the second bioreactor and $6000-6500 \mathrm{mg} / \mathrm{L}$ as $\mathrm{CaCO}_{3}$ and $\mathrm{pH}$ 7.2-7.5 for the third bioreactor), especially in the third bioreactor, resulting in most of the produced $\mathrm{H}_{2} \mathrm{~S}$ (less than $50 \mathrm{ppm}$ in all three bioreactors under the studied COD loading rate) being neutralized. As a result, the system had a lower available amount of free sulfide $\left(\mathrm{S}^{2-}\right)$ to react with all the micronutrients (divalent cations). 
Table 2. Micronutrient concentrations in the three-stage ASBR system operated at $37^{\circ} \mathrm{C}$ at different COD loading rates.

\begin{tabular}{|c|c|c|c|c|c|c|c|c|c|c|c|}
\hline \multirow{4}{*}{$\begin{array}{c}\text { Trace } \\
\text { Element }\end{array}$} & \multicolumn{11}{|c|}{ Concentration $(\mathrm{mg} / \mathrm{L})$} \\
\hline & \multirow{3}{*}{$\begin{array}{c}\text { Theoretical } \\
\text { Values for } \\
\text { Anaerobic } \\
\text { Digestion [36] }\end{array}$} & \multirow{3}{*}{ Feed } & \multirow{2}{*}{\multicolumn{3}{|c|}{$\begin{array}{c}\text { COD Loading Rate of } \\
15 \mathrm{~kg} / \mathrm{m}^{3} \mathrm{~d} \\
\text { Effluent of } \\
\end{array}$}} & \multirow{2}{*}{\multicolumn{3}{|c|}{$\begin{array}{c}\text { COD Loading Rate of } \\
18 \mathrm{~kg} / \mathrm{m}^{3} \mathrm{~d} \\
\text { Effluent of }\end{array}$}} & \multirow{2}{*}{\multicolumn{3}{|c|}{$\begin{array}{c}\text { COD Loading Rate of } \\
21 \mathrm{~kg} / \mathrm{m}^{3} \mathrm{~d} \\
\text { Effluent of } \\
\end{array}$}} \\
\hline & & & & & & & & & & & \\
\hline & & & $\begin{array}{c}\text { 1st } \\
\text { ASBR } \\
\text { Unit }\end{array}$ & $\begin{array}{c}\text { 2nd } \\
\text { ASBR } \\
\text { Unit }\end{array}$ & $\begin{array}{c}\text { 3rd } \\
\text { ASBR } \\
\text { Unit }\end{array}$ & $\begin{array}{c}\text { 1st } \\
\text { ASBR } \\
\text { Unit }\end{array}$ & $\begin{array}{c}\text { 2nd } \\
\text { ASBR } \\
\text { Unit }\end{array}$ & $\begin{array}{c}\text { 3rd } \\
\text { ASBR } \\
\text { Unit }\end{array}$ & $\begin{array}{c}\text { 1st } \\
\text { ASBR } \\
\text { Unit }\end{array}$ & $\begin{array}{c}\text { 2nd } \\
\text { ASBR } \\
\text { Unit }\end{array}$ & $\begin{array}{c}\text { 3rd } \\
\text { ASBR } \\
\text { Unit }\end{array}$ \\
\hline $\mathrm{Co}^{2+}$ & $0.10-5.00$ & 0.11 & 0.17 & 0.13 & 0.11 & 0.19 & 0.17 & 0.15 & 0.17 & 0.17 & 0.15 \\
\hline $\mathrm{Cu}^{2+}$ & $0.01-0.05$ & 0.20 & 0.11 & 0.09 & 0.03 & 0.10 & 0.06 & 0.06 & 0.93 & 0.13 & 0.09 \\
\hline $\mathrm{Fe}^{2+}$ & $0.10-0.40$ & 36.12 & 37.97 & 7.49 & 5.32 & 47.21 & 20.94 & 7.45 & 29.76 & 25.45 & 6.36 \\
\hline $\mathrm{Mn}^{2+}$ & $0.01-0.05$ & 4.94 & 3.10 & 1.47 & 0.83 & 3.43 & 3.36 & 0.87 & 1.69 & 1.39 & 0.75 \\
\hline $\mathrm{Mo}^{2+}$ & $0.10-0.70$ & 1.20 & 0.32 & 0.32 & 0.32 & 0.74 & 0.63 & 0.21 & 0.42 & 0.21 & 0.21 \\
\hline $\mathrm{Ni}^{2+}$ & $0.05-0.30$ & 0.21 & 0.24 & 0.22 & 0.19 & 0.28 & 0.17 & 0.16 & 0.26 & 0.22 & 0.16 \\
\hline $\mathrm{Zn}^{2+}$ & $0.10-1.00$ & 1.41 & 0.44 & 0.43 & 0.27 & 1.37 & 0.30 & 0.26 & 4.40 & 0.53 & 0.25 \\
\hline
\end{tabular}

\subsection{Part II: Effect of the Bioreactor Volumetric Ratio}

In this part, the effect of a bioreactor volumetric ratio was investigated under the base operational conditions $\left(8\right.$ cycles $/ \mathrm{d}, 37{ }^{\circ} \mathrm{C}$, COD loading rate of $18 \mathrm{~kg} / \mathrm{m}^{3} \mathrm{~d}$ and total ASBR volume of $30 \mathrm{~L}$ ) by varying the liquid working volumetric ratio of the first:second:third bioreactors of 4:6:20, 5:5:20, 4:8:18 and 6:6:18 in order to determine the optimum bioreactor volumetric ratio for maximizing $\mathrm{CH}_{4}$ production.

\subsubsection{Overall COD Removal and Gas Production Rate}

Figure 6a shows the effect of the bioreactor volumetric ratio on the overall COD removal and the overall gas production rate. Both the overall COD removal and gas production rate showed a similar trend with a maximum overall COD removal level $(92.1 \%)$ and gas production rate $(7.6 \mathrm{~L} / \mathrm{d})$ being obtained at the bioreactor volumetric ratio of 5:5:20, compared to $83.5 \%$ and $3.7 \mathrm{~L} / \mathrm{d}$, respectively, at a bioreactor volumetric ratio of 6:6:18, which corresponded to the results of MLVSS as discussed in Section 3.2.7.

\subsubsection{Gas Composition of Mixed Gas}

The composition of the mixed gas produced from the three bioreactors as a function of the volumetric ratio of the three bioreactors is shown in Figure $6 \mathrm{~b}$. The highest $\mathrm{CH}_{4}$ and lowest $\mathrm{CO}_{2}$ content were found at a bioreactor volumetric ratio of 4:6:20. However, the maximum $\mathrm{H}_{2}$ content was found at a volumetric ratio of 5:5:20, which correlated to the highest of MLVSS in the first ASBR bioreactor at this volumetric ratio, as further explained in Section 3.2.7. Moreover, it clearly showed that the volumetric ratio of 6:6:18 provided a higher value of $\mathrm{CO}_{2}$ content than $\mathrm{CH}_{4}$, suggesting that the lowest volume of the third bioreactor gave the lowest rate of the methanogenesis.

\subsubsection{Overall $\mathrm{H}_{2}$ and $\mathrm{CH}_{4}$ Production Rates}

Figure $6 \mathrm{c}$ shows the effect of the volumetric ratio on the $\mathrm{H}_{2}$ and $\mathrm{CH}_{4}$ production rates of the three-stage ASBR system operated at the constant COD loading rate of $18 \mathrm{~kg} / \mathrm{m}^{3} \mathrm{~d}$. Both the $\mathrm{H}_{2}$ and $\mathrm{CH}_{4}$ production rates had similar trends to the gas production rates (Figure 6a). The three-stage ASBR system operated at the volumetric ratio of 5:5:20 also gave the highest $\mathrm{H}_{2}$ and $\mathrm{CH}_{4}$ production rates, suggesting that this volumetric ratio provided the highest activities for all three steps-acidogenesis, acetogenesis and methanogenesis-corresponding to the highest microbial concentrations in all three bioreactors as discussed in Section 3.2.7. 


\subsubsection{Overall $\mathrm{H}_{2}$ and $\mathrm{CH}_{4}$ Yields}

The overall $\mathrm{H}_{2}$ and $\mathrm{CH}_{4}$ yields, based on both the COD applied and COD removed as a function of the volumetric ratio of the three-stage ASBR system are shown in Figure 6d,e, respectively. The three-stage ASBR system with a volumetric ratio of 5:5:20 provided the highest yields of both overall $\mathrm{H}_{2}$ and $\mathrm{CH}_{4}$, corresponding to the highest MLVSS values of all three bioreactors, as discussed in Section 3.2.7. Note that the effect of the volumetric ratio on the overall yields of $\mathrm{H}_{2}$ and $\mathrm{CH}_{4}$ was much greater than that on the overall COD removal.

\subsubsection{Specific Energy Production Rate and Yield of Mixed Gas}

The specific energy production rate and yield of the mixed gas as a function of the bioreactor volumetric ratio are shown in Figure 6f. The values of the specific energy production rate and yield of the mixed gas were calculated based on the heating values of $\mathrm{H}_{2}$ and $\mathrm{CH}_{4}$ of 242 and $801 \mathrm{~kJ} / \mathrm{mol}$, respectively $[1,39,40]$. The profiles of both the specific energy production rate and yield showed similar trends to that of the $\mathrm{CH}_{4}$ yield since the mixed gas mostly contained $\mathrm{CH}_{4}$ with a very small portion of $\mathrm{H}_{2}$. At the optimum bioreactor volumetric ratio of 5:5:20, the system gave the highest process performance in terms of overall COD removal, gas production rates and yields and specific energy production rate and yield.
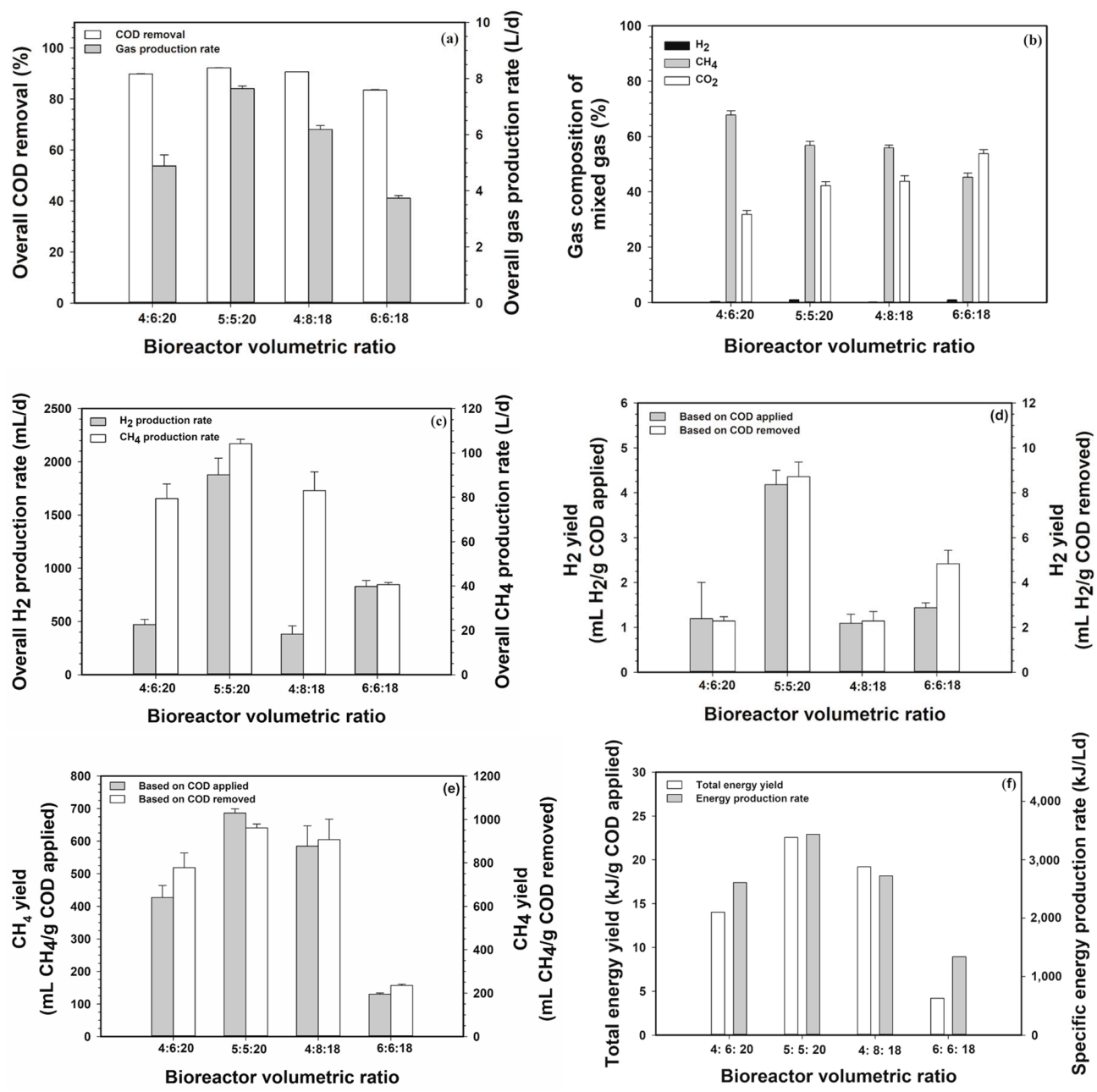

Figure 6. Effect of the bioreactor volumetric ratio on the (a) overall COD removal and overall gas production rate, (b) composition of mixed gas, (c) $\mathrm{H}_{2}$ and $\mathrm{CH}_{4}$ production rates of mixed gas, (d) $\mathrm{H}_{2}$ yields, (e) $\mathrm{CH}_{4}$ yields and (f) total energy yield and specific energy production rate of mixed gas when the three-stage ASBR system was operated at a COD loading rate of $18 \mathrm{~kg} / \mathrm{m}^{3} \mathrm{~d}, 37^{\circ} \mathrm{C}$ and 8 cycles $/ \mathrm{d}$. 


\subsubsection{VFA Levels}

The total VFA concentration in each bioreactor as a function of the volumetric ratio is shown in Figure 7, where the total VFA concentration in each bioreactor tended to increase when the volumetric ratio increased. The increasing volumetric ratio simply increased either the volume of the first or second bioreactor, leading to an increase in either the acidogenic or acetogenic activity at the expense of the methanogenic activity. Interestingly, the formation of HLa appeared only in the first bioreactor with low volumetric ratios of 4:6:20 and 5:5:20, suggesting that the high COD loading rate conditions caused the formation of HLa.
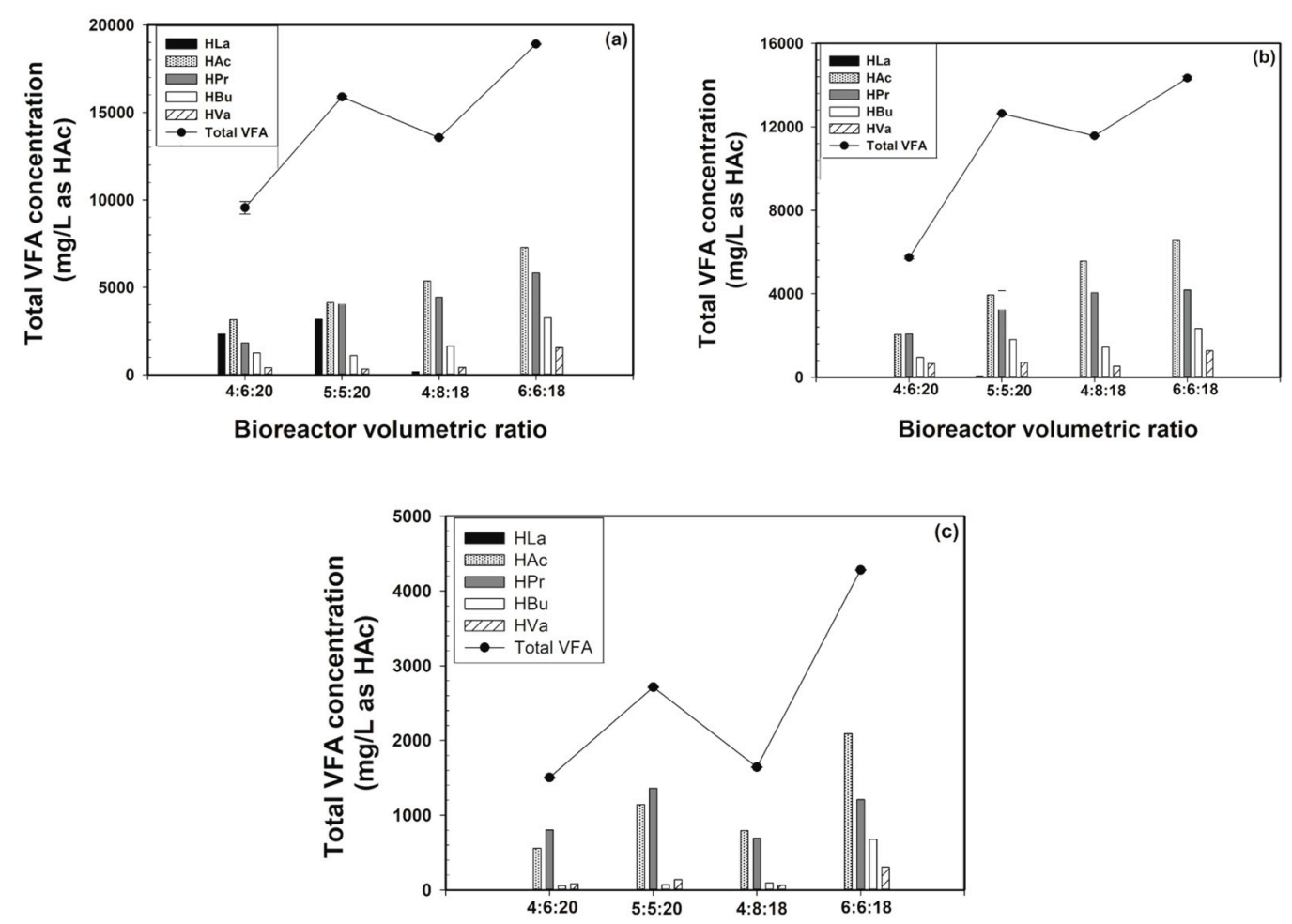

Figure 7. Effect of the bioreactor volumetric ratio on the total VFA concentration and VFA composition of the (a) first, (b) second and (c) third bioreactors when the three-stage ASBR system was operated at a COD loading rate of $18 \mathrm{~kg} / \mathrm{m}^{3} \mathrm{~d}, 37^{\circ} \mathrm{C}$ and 8 cycles $/ \mathrm{d}$.

\subsubsection{Microbial Concentrations}

The MLVSS values of each bioreactor at different volumetric ratios are shown in Figure 8. Interestingly, the volumetric ratio of 5:5:20 provided the highest microbial concentrations (MLVSS) in all three bioreactors, suggesting that a good balance of all three steps (acidogenesis, acetogenesis and methanogenesis) was achieved at this volumetric ratio. Thus, either higher or lower volumetric ratios than the optimum could lead to increased microbial washout from all bioreactors. The highest obtained microbial concentration at the optimum volumetric ratio of 5:5:20 was responsible for the maximum process performance of the studied three-stage ASBR system in terms of gas yields and COD removal. 


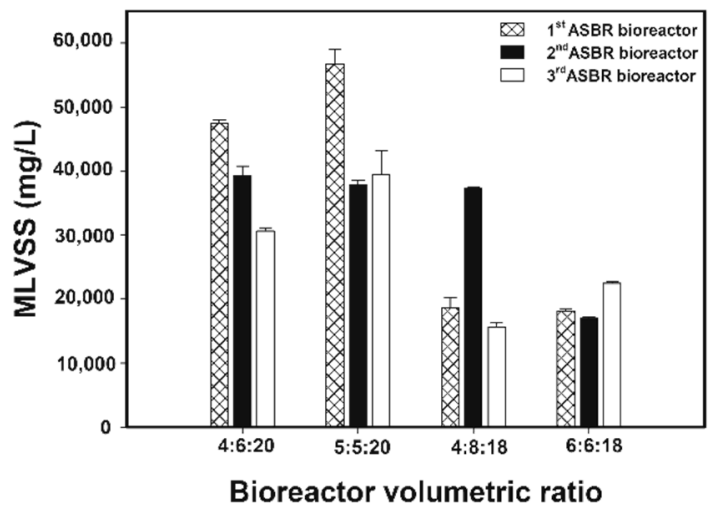

Figure 8. Effect of the bioreactor volumetric ratio on the MLVSS when the three-stage ASBR system was operated at a COD loading rate of $18 \mathrm{~kg} / \mathrm{m}^{3} \mathrm{~d}, 37^{\circ} \mathrm{C}$ and 8 cycles $/ \mathrm{d}$.

\subsubsection{Comparison of Process Performance}

As shown in Table 3, the studied three-stage ASBR system exhibited a superior process performance, specifically, a much higher optimum COD loading rate and energy production yield, compared to both single- and two-stage anaerobic processes treating various wastewaters. This is because the three-stage ASBR system is able to provide very high concentrations of microbial cells in all bioreactors and proper environmental conditions in each bioreactor for the main three steps of anaerobic digestion.

Table 3. Comparison of the three-stage ASBR system with other studies.

\begin{tabular}{|c|c|c|c|c|c|c|c|c|c|}
\hline System & Substrate & Production & $\begin{array}{c}\text { Optimum } \\
\text { COD Loading } \\
\text { Rate }\left(\mathrm{kg} / \mathrm{m}^{3} \mathrm{~d}\right)\end{array}$ & $\begin{array}{c}\text { Temperature } \\
\left({ }^{\circ} \mathrm{C}\right)\end{array}$ & $\begin{array}{l}\text { Volume of } \\
\text { Bioreactor } \\
\text { (L) }\end{array}$ & $\begin{array}{c}\mathrm{CH}_{4} \text { Yield } \\
\text { (mL CH } \mathrm{CH}_{4} / \mathrm{g} \\
\text { COD Applied) }\end{array}$ & $\begin{array}{c}\text { Energy Yield } \\
\text { (kJ/g COD } \\
\text { Applied) }\end{array}$ & $\begin{array}{c}\text { Overall } \\
\text { COD } \\
\text { Removal (\%) }\end{array}$ & Reference \\
\hline $\begin{array}{l}\text { One-stage } \\
\text { ASBR }\end{array}$ & Alcohol & $\mathrm{H}_{2}$ & 60 & 37 & 4 & - & 0.50 & 32 & [41] \\
\hline $\begin{array}{l}\text { One-stage } \\
\text { ASBR }\end{array}$ & Ethanol & $\mathrm{H}_{2}$ & 50.6 & 55 & 4 & - & 0.29 & 32 & [27] \\
\hline $\begin{array}{l}\text { One-stage } \\
\text { ASBR }\end{array}$ & Ethanol & $\mathrm{CH}_{4}$ & $\begin{array}{c}6 \\
10\end{array}$ & $\begin{array}{l}37 \\
55\end{array}$ & 2 & $\begin{array}{l}231 \\
324\end{array}$ & $\begin{array}{c}8.60 \\
10.90\end{array}$ & $\begin{array}{l}93 \\
83\end{array}$ & [6] \\
\hline $\begin{array}{c}\text { Two-stage } \\
\text { UASB }\end{array}$ & Cassava & $\mathrm{H}_{2} \& \mathrm{CH}_{4}$ & 7 & 37 & 4 and 24 & 115 & 4.39 & 96 & [19] \\
\hline $\begin{array}{c}\text { Two-stage } \\
\text { CSTR }\end{array}$ & $\begin{array}{l}\text { Cheese } \\
\text { whey }\end{array}$ & $\mathrm{H}_{2} \& \mathrm{CH}_{4}$ & NR & 35 & 3 and 15 & 310 & 0.41 & 94 & [42] \\
\hline $\begin{array}{c}\text { Two-stage } \\
\text { UASB }\end{array}$ & Cassava & $\mathrm{H}_{2} \& \mathrm{CH}_{4}$ & 13 & 55 & 4 and 24 & 165 & 6.49 & 82 & [24] \\
\hline $\begin{array}{c}\text { Three-stage } \\
\text { UASB }\end{array}$ & Cassava & $\mathrm{H}_{2} \& \mathrm{CH}_{4}$ & 15 & 37 & 4,10 and 24 & 328 & 11.76 & 92.5 & [18] \\
\hline $\begin{array}{c}\text { Three-stage } \\
\text { ASBR }\end{array}$ & Ethanol & $\mathrm{H}_{2} \& \mathrm{CH}_{4}$ & 18 & 37 & 5,5 and 20 & 686 & 22.50 & 92.1 & $\begin{array}{l}\text { Present } \\
\text { work }\end{array}$ \\
\hline
\end{tabular}

NR: Not reported.

\section{Conclusions}

A three-stage ASBR system was developed and tested for the separate production of $\mathrm{H}_{2}$ and $\mathrm{CH}_{4}$ with an emphasis on $\mathrm{CH}_{4}$ production by recycling both the effluent and washout sludge from the third bioreactor to the first bioreactor. The studied three-stage ASBR system had a very high optimum COD loading rate of $18 \mathrm{~kg} / \mathrm{m}^{3} \mathrm{~d}$ because of the very high microbial concentrations in all three bioreactors without any deficit of micronutrients, due to the high alkalinity and solution $\mathrm{pH}$ in the system, especially in the third bioreactor. Under the optimum COD loading rate condition of $18 \mathrm{~kg} / \mathrm{m}^{3} \mathrm{~d}$ and bioreactor volumetric ratio of 5:5:20, the three-stage ASBR system provided a very high energy production yield compared with the single- and two-stage anaerobic processes used for treating various wastewaters. 
Author Contributions: Conceptualization, A.J., K.V., M.L. and S.C.; Methodology, A.J. and K.V.; Software, A.J.; Validation, A.J., K.V. and S.C.; Formal Analysis, A.J. and K.V.; Investigation, A.J. and K.V.; Resources, S.C.; Data Curation, A.J.; Writing-Original Draft Preparation, A.J.; Writing-Review \& Editing, M.L. and S.C.; Visualization, A.J.; Supervision, S.C.; Project Administration, S.C.; Funding Acquisition, S.C.

Funding: This research was funded by a TRF senior scholar grant from the Thailand Research Fund (RTA 5780008), a TRF research grant (RDG 6050068), a research grant from The Minister of Energy (459042-AE1) and a research grant from National Science and Technology Development Agency (NSTDA, P-15-51254).

Acknowledgments: The authors thank Sapthip Co., Ltd., Thailand for providing the seed sludge and ethanol wastewater. The sustainable Petroleum and Petrochemicals Research Unit under the Center of Excellence on Petrochemical and Materials Technology, Chulalongkorn University is also acknowledged for providing research facilities and partial financial support.

Conflicts of Interest: The authors declare no conflict of interest.

\section{Nomenclature}

$\begin{array}{ll}\text { ASBR } & \text { Anaerobic sequencing batch reactor } \\ \text { COD } & \text { Chemical oxygen demand } \\ \text { CSTR } & \text { Complete stirred tank reactor } \\ \mathrm{Co}, \mathrm{Co}^{2+} & \text { Cobalt } \\ \mathrm{Cu}, \mathrm{Cu}^{2+} & \text { Copper } \\ \mathrm{Fe}, \mathrm{Fe}^{2+} & \text { Iron } \\ \mathrm{H}_{2} \mathrm{~S} & \text { Hydrogen sulfide } \\ \mathrm{M}^{2+} & \text { Micronutrients (divalent cations) } \\ \mathrm{MLVSS}_{\mathrm{M}} & \text { Mixed liquor volatile suspended solids } \\ \mathrm{Mn}, \mathrm{Mn}^{2+} & \text { Manganese } \\ \mathrm{MS} & \text { Metal sulfides } \\ \mathrm{Mo}, \mathrm{Mo}^{2+} & \text { Molybdenum } \\ \mathrm{Ni}, \mathrm{Ni}^{2+} & \text { Nickle } \\ \mathrm{N} & \text { Nitrogen } \\ \mathrm{P} & \text { Phosphorous } \\ \mathrm{SHPR} & \text { Specific hydrogen production rate } \\ \mathrm{SMPR} & \text { Specific methane production rate } \\ \text { TCD } & \text { Thermal conductivity detector } \\ \text { TSS } & \text { Total suspended solids } \\ \text { VFA } & \text { Volatile fatty acids } \\ \text { VSS } & \text { Volatile suspended solids } \\ \mathrm{UASB} & \text { Upflow anaerobic sludge blanket } \\ \mathrm{Zn}, \mathrm{Zn}^{2+} & \text { Zinc }\end{array}$

\section{References}

1. Lin, R.; Cheng, J.; Yang, Z.; Ding, L.; Zhang, J.; Zhou, J.; Cen, K. Enhanced energy recovery from cassava ethanol wastewater through sequential dark hydrogen, photo hydrogen and methane fermentation combined with ammonium removal. Bioresour. Technol. 2016, 214, 686-691. [CrossRef] [PubMed]

2. Stamatelatou, K.; Antonopoulou, G.; Lyberatos, G. Production of biogas via anaerobic digestion. Handb. Biofuels Prod. Process. Technol. 2011, 266-304. [CrossRef]

3. Lin, C.-Y.; Lay, C.-H.; Sen, B.; Chu, C.-Y.; Kumar, G.; Chen, C.-C.; Chang, J.-S. Fermentative hydrogen production from wastewaters: A review and prognosis. Int. J. Hydrogen Energy 2012, 37, 15632-15642. [CrossRef]

4. Demirel, B. The impacts of engineered nanomaterials (ENMs) on anaerobic digestion processes. Process Biochem. 2016, 51, 308-313. [CrossRef]

5. Sreethawong, T.; Niyamapa, T.; Neramitsuk, H.; Rangsunvigit, P.; Leethochawalit, M.; Chavadej, S. Hydrogen production from glucose-containing wastewater using an anaerobic sequencing batch reactor: Effects of COD loading rate, nitrogen content, and organic acid composition. Chem. Eng. J. 2010, 160, 322-332. [CrossRef]

6. Seneesrisakul, K.; Sutabutr, T.; Chavadej, S. The effect of temperature on the methanogenic activity in relation to micronutrient availability. Energies 2018, 11, 1057. [CrossRef] 
7. Papurello, D.; Iafrate, C.; Lanzini, A.; Santarelli, M. Trace compounds impact on SOFC performance: Experimental and modelling approach. Appl. Energy 2017, 208, 637-654. [CrossRef]

8. Papurello, D.; Tomasi, L.; Silvestri, S.; Belcari, I.; Santarelli, M.; Smeacetto, F.; Biasioli, F. Biogas trace compound removal with ashes using proton transfer reaction time-of-flight mass spectrometry as innovative detection tool. Fuel Process. Technol. 2016, 145, 62-75. [CrossRef]

9. Papurello, D.; Silvestri, S.; Tomasi, L.; Belcari, I.; Biasioli, F.; Santarelli, M. Biowaste for SOFCs. Energy Procedia 2016, 101, 424-431. [CrossRef]

10. Molino, A.; Larocca, V.; Chianese, S.; Musmarra, D. Biofuels production by biomass gasification: A review. Energies 2018, 11, 811. [CrossRef]

11. Liu, D.; Liu, D.; Zeng, R.J.; Angelidaki, I. Hydrogen and methane production from household solid waste in the two-stage fermentation process. Water Res. 2006, 40, 2230-2236. [CrossRef] [PubMed]

12. Liu, X.; Li, R.; Ji, M.; Han, L. Hydrogen and methane production by co-digestion of waste activated sludge and food waste in the two-stage fermentation process: Substrate conversion and energy yield. Bioresour. Technol. 2013, 146, 317-323. [CrossRef] [PubMed]

13. Diamantis, V.I.; Aivasidis, A. Comparison of single-and two-stage UASB reactors used for anaerobic treatment of synthetic fruit wastewater. Enzyme Microb. Technol. 2007, 42, 6-10. [CrossRef]

14. Monlau, F.; Kaparaju, P.; Trably, E.; Steyer, J.P.; Carrere, H. Alkaline pretreatment to enhance one-stage $\mathrm{CH}_{4}$ and two-stage $\mathrm{H}_{2} / \mathrm{CH}_{4}$ production from sunflower stalks: Mass, energy and economical balances. Chem. Eng. J. 2015, 260, 377-385. [CrossRef]

15. La Licata, B.; Sagnelli, F.; Boulanger, A.; Lanzini, A.; Leone, P.; Zitella, P.; Santarelli, M. Bio-hydrogen production from organic wastes in a pilot plant reactor and its use in a SOFC. Int. J. Hydrogen Energy 2011, 36, 7861-7865. [CrossRef]

16. Sompong, O.; Suksong, W.; Promnuan, K.; Thipmunee, M.; Mamimin, C.; Prasertsan, P. Two-stage thermophilic fermentation and mesophilic methanogenic process for biohythane production from palm oil mill effluent with methanogenic effluent recirculation for $\mathrm{pH}$ control. Int. J. Hydrogen Energy 2016, 41, 21702-21712. [CrossRef]

17. Müller, F.; Maack, G.-C.; Buescher, W. Effects of biogas substrate recirculation on methane yield and efficiency of a liquid-manure-based biogas plant. Energies 2017, 10, 325. [CrossRef]

18. Jiraprasertwong, A. Production of biogas from cassava wastewater using a three-stage upflow anaerobic sludge blanket (UASB) reactor. Renew. Energ. 2018, in press.

19. Intanoo, P.; Chaimongkol, P.; Chavadej, S. Hydrogen and methane production from cassava wastewater using two-stage upflow anaerobic sludge blanket reactors (UASB) with an emphasis on maximum hydrogen production. Int. J. Hydrogen Energy 2016, 41, 6107-6114. [CrossRef]

20. Sreethawong, T.; Chatsiriwatana, S.; Rangsunvigit, P.; Chavadej, S. Hydrogen production from cassava wastewater using an anaerobic sequencing batch reactor: Effects of operational parameters, COD: N ratio, and organic acid composition. Int. J. Hydrogen Energy 2010, 35, 4092-4102. [CrossRef]

21. Lay, J.-J.; Lee, Y.-J.; Noike, T. Feasibility of biological hydrogen production from organic fraction of municipal solid waste. Water Res. 1999, 33, 2579-2586. [CrossRef]

22. Argun, H.; Kargi, F.; Kapdan, I.K.; Oztekin, R. Biohydrogen production by dark fermentation of wheat powder solution: Effects of $\mathrm{C} / \mathrm{N}$ and $\mathrm{C} / \mathrm{P}$ ratio on hydrogen yield and formation rate. Int. J. Hydrogen Energy 2008, 33, 1813-1819. [CrossRef]

23. Intanoo, P.; Rangsunvigit, P.; Namprohm, W.; Thamprajamchit, B.; Chavadej, J.; Chavadej, S. Hydrogen production from alcohol wastewater by an anaerobic sequencing batch reactor under thermophilic operation: Nitrogen and phosphorous uptakes and transformation. Int. J. Hydrogen Energy 2012, 37, 11104-11112. [CrossRef]

24. Intanoo, P.; Rangsanvigit, P.; Malakul, P.; Chavadej, S. Optimization of separate hydrogen and methane production from cassava wastewater using two-stage upflow anaerobic sludge blanket reactor (UASB) system under thermophilic operation. Bioresour. Technol. 2014, 173, 256-265. [CrossRef] [PubMed]

25. Watcharanurak, T. Three-Stage ASBR System for Separate Production of H2 and CH4 from Ethanol Wastewater. Master's Thesis, The Petroleum and Petrochemical College, Chulalongkorn University, Bangkok, Thailand, 2016. 
26. Association, A.P.H.; Association, A.W.W.; Federation, W.P.C.; Federation, W.E. Standard Methods for the Examination of Water and Wastewater, 23th ed.; American Public Health Association: Washington, DC, USA, 2017; Volume 1.

27. Intanoo, P.; Suttikul, T.; Leethochawalit, M.; Gulari, E.; Chavadej, S. Hydrogen production from alcohol wastewater with added fermentation residue by an anaerobic sequencing batch reactor (ASBR) under thermophilic operation. Int. J. Hydrogen Energy 2014, 39, 9611-9620. [CrossRef]

28. Venkata Mohan, S.; Mohanakrishna, G.; Sarma, P.N. Integration of acidogenic and methanogenic processes for simultaneous production of biohydrogen and methane from wastewater treatment. Int. J. Hydrogen Energy 2008, 33, 2156-2166. [CrossRef]

29. Balachandar, G.; Khanna, N.; Das, D. Biohydrogen production from organic wastes by dark fermentation-Chapter 6. Biohydrogen 2013, 103-144. [CrossRef]

30. Ali Shah, F.; Mahmood, Q.; Maroof Shah, M.; Pervez, A.; Ahmad Asad, S. Microbial ecology of anaerobic digesters: The key players of anaerobiosis. Sci. World J. 2014, 2014, 183752. [CrossRef] [PubMed]

31. Linville, J.L.; Shen, Y.; Schoene, R.P.; Nguyen, M.; Urgun-Demirtas, M.; Snyder, S.W. Impact of trace element additives on anaerobic digestion of sewage sludge with in-situ carbon dioxide sequestration. Process Biochem. 2016, 51, 1283-1289. [CrossRef]

32. Burgess, J.E.; Quarmby, J.; Stephenson, T. Micronutrient supplements for optimisation of the treatment of industrial wastewater using activated sludge. Water Res. 1999, 33, 3707-3714. [CrossRef]

33. Choong, Y.Y.; Norli, I.; Abdullah, A.Z.; Yhaya, M.F. Impacts of trace element supplementation on the performance of anaerobic digestion process: A critical review. Bioresour. Technol. 2016, 209, 369-379. [CrossRef] [PubMed]

34. Voelklein, M.A.; O' Shea, R.; Jacob, A.; Murphy, J.D. Role of trace elements in single and two-stage digestion of food waste at high organic loading rates. Energy 2017, 121, 185-192. [CrossRef]

35. Zhang, L.; De Schryver, P.; De Gusseme, B.; De Muynck, W.; Boon, N.; Verstraete, W. Chemical and biological technologies for hydrogen sulfide emission control in sewer systems: A review. Water Res. 2008, 42, 1-12. [CrossRef] [PubMed]

36. Demirel, B.; Scherer, P. Trace element requirements of agricultural biogas digesters during biological conversion of renewable biomass to methane. Biomass Bioenergy 2011, 35, 992-998. [CrossRef]

37. Thanh, P.M.; Ketheesan, B.; Yan, Z.; Stuckey, D. Trace metal speciation and bioavailability in anaerobic digestion: A review. Biotechnol. Adv. 2016, 34, 122-136. [CrossRef] [PubMed]

38. Narra, M.; Balasubramanian, V.; Kurchania, A.; Pathak, B.S.; Shyam, M. Enhanced biogas production from rice straw by selective micronutrients under solid state anaerobic digestion. Bioresour. Technol. 2016, 220, 666-671. [CrossRef] [PubMed]

39. Cheng, J.; Xie, B.; Zhou, J.; Song, W.; Cen, K. Cogeneration of $\mathrm{H}_{2}$ and $\mathrm{CH}_{4}$ from water hyacinth by two-step anaerobic fermentation. Int. J. Hydrogen Energy 2010, 35, 3029-3035. [CrossRef]

40. Wang, Y.; Zhang, Y.; Meng, L.; Wang, J.; Zhang, W. Hydrogen-methane production from swine manure: Effect of pretreatment and VFAs accumulation on gas yield. Biomass Bioenergy 2009, 33, 1131-1138. [CrossRef]

41. Searmsirimongkol, P.; Rangsunvigit, P.; Leethochawalit, M.; Chavadej, S. Hydrogen production from alcohol distillery wastewater containing high potassium and sulfate using an anaerobic sequencing batch reactor. Int. J. Hydrogen Energy 2011, 36, 12810-12821. [CrossRef]

42. Antonopoulou, G.; Stamatelatou, K.; Venetsaneas, N.; Kornaros, M.; Lyberatos, G. Biohydrogen and methane production from cheese whey in a two-stage anaerobic process. Ind. Eng. Chem. Res. 2008, 47, 5227-5233. [CrossRef]

(C) 2018 by the authors. Licensee MDPI, Basel, Switzerland. This article is an open access article distributed under the terms and conditions of the Creative Commons Attribution (CC BY) license (http:/ / creativecommons.org/licenses/by/4.0/). 